2. All Ss were run during the second and third day of classes, and the test questions were on topics usually covered during the last half of the course. In all cases this was the first psychological experiment the $S$ had participated in.

3. The test he had administered was the Self-esteem Scale of the California Psychological Inventory. The students had been told that the test was a personality inventory and was being administered to obtain information concerning the characteristics of Mississippi State students. They were told that they would receive their individual results in a few days.

\title{
CURRENT LITERATURE ON SOCIAL PROCESSES
}

ATWOOD, R. W. (Brigham Young University, Provo, Utah 84601), \& HOWELL, R. J. Pupillometric and personality test score differences of female aggressing pedophiliacs and normals. Psychonomic Science, 1971, 22, 115-116.

BLANK, E. P. (Johns Hopkins University, Baltimore, Md. 21218), \& ARENSON, S. J. Effects of previous order and proportion of similar attitude statements on attraction during a subsequent series of dissimilar statements. Psychonomic Science, 1971, 22, 245-246.

DUSTIN, D. S. (New York State University College, Plattsburgh, N.Y. 12901), \& ALFONSIN, B. Similarity and liking. Psychonomic Science, 1971, 22, 119.

JOHNSON, H. H. (Loyola University of Chicago, Chicago, nl. 60626), \& WATKINS, T. A. The effects of message repetitions on immediate and delayed attitude change. Psychonomic Science, 1971, 22, 101-103.

LA GAIPA, J. J. (University of Windsor, Windsor, Ontario, Canada), \& WERNER, R. E. Attraction and relevancy of attitude similarity-dissimilarity: Impersonal topics and friendship beliefs. Psychonomic Science, 1971, 22, 83-84.
LANE, I. M. (Louisiana State University, Baton Rouge, La. 70803), MESSE, L. A., \& PHILLIPS, J. L. Differential inputs as a determinant in the selection of a distributor of rewards. Psychonomic Science, 1971, 22, 228-229.

LINDSKOLD, S. (Ohio University, Athens, Ohio 45701), \& TEDESCHI, J. T. Reward power and attraction in interpersonal conflict. Psychonomic Science, $1971,22,211-213$.

MILLS, J. (University of Missouri, Columbia, Mo. 65201), \& O'NEAL, E. Anticipated choice, attention, and halo effect. Psychonomic Science, 1971, 22, 231-233.

MONTGOMERY, R. L. (University of Missouri, Rolla, Mo. 65401), \& ENZIE, R. F. Social influence and the estimation of time. Psychonomic Science, 1971, 22, 77-78.

ROUBERTOUX, P. (Institut d'esthétique et des sciences de l'art, University of Paris, 75-Paris, 5eme France), CARLIER, M., \& CHAGUibofF, J. Preference for non-objective art: Personal and psychosocial determiners. British Journal of Psychology, 1971, 62, 105-110.

SHAW, M. E. (University of Florida, Gainesville, Fla. 32601), \& BREED,
G. R. Some effects of attribution of responsibility upon the effectiveness of small problem-solving groups. Psychonomic Science, 1971, 22, 207-209.

SISTRUNK, F. (State University System of Florida, 107 West Gaines Street, Tallahassee, Fla. 2304). Interactions of source prestige, goal set, and task difficulty in conforming behavior. Psychonomic Science, 1971, 22, 109-111.

SMITH, R. E. (University of Washington, Seattle, Wash. 98105). Observational learning of modeled responses under shock-avoidance conditions as a function of attitude similarity and attraction toward the model. Psychonomic Science, 1971, $22,123-124$.

SUTTON, A. J. (School of Behavioural Sciences, Macquarie University, New South Wales, Australia). The use of quadratic discriminant analysis for the measurement of profile distance in social perception. British Journal of Psychology, $1971,62,253-260$.

WEISS, R. F. (University of Oklahoma, Norman, Okla. 73069), MILLER, F. G., LANGAN, C. J., \& CECIL, J. S. Social facilitation of attitude change. Psychonomic Science, 1971, 22, 113-114. 